\title{
Synergistic, Attenuative and Modulatory Activity in Dimethylnitrosamine (DMN)-induced Fibrotic Rats Treated with Vernonia Amygdalina and Annona Muricata Leaves
}

\author{
Usunobun Usunomena*1 and Okolie, Ngozi Paulinus² \\ ${ }^{1}$ Department of Biochemistry, Faculty of Basic Medical Sciences, College of Medical Sciences, Edo University, \\ Iyamho, Edo state, Nigeria \\ ${ }^{2}$ Department of Biochmistry, Faculty of Life Sciences. University of Benin, Edo State, Nigeria \\ "Corresponding Author \\ Usunobun Usunomena \\ Department of Biochemistry, Faculty of Basic Medical Sciences, College of Medical Sciences \\ Edo University, Iyamho, Edo state \\ Nigeria \\ Email: usunobun.usunomena@edouniversity.edu.ng \\ Phone: +2348034174871
}

Received:03 August 2019; | Revised:21 May 2021; | Accepted:5 June 2021

\section{Abstract}

Background: This study assessed the effect of Vernonia amygdalina and Annona muricata leaves in a combine dose on oxidative stress and extracellular matrix parameters in liver fibrosis induced by dimethylnitrosamine (DMN).

Methods: One group, the control received physiological saline; Second group was given 100mg/kg each of Vernonia amygdalina and Annona muricata ethanol leaf extract without DMN orally for 14 consecutive days. The third group received intra-peritoneal injection of $10 \mathrm{mg}$ of DMN $/ \mathrm{kg}$ body weight three times a week (on the first three days) for two weeks, in addition to $100 \mathrm{mg} / \mathrm{kg}$ each of Vernonia amygdalina and Annona muricata which were administered for 14 days consecutively while the last group was given only $10 \mathrm{mg}$ of $\mathrm{DMN} / \mathrm{kg}$. 14 days later, the rats were sacrificed, blood samples collected and sera analysed for hyaluronic acid (HA), alkaline phosphatase (ALP), alanine transaminase (ALT) and aspartate transaminase (AST) while collagen, catalase (CAT), reduced glutathione (GSH), superoxide dismutase (SOD) and malondialdehyde (MDA) levels were assayed in liver tissue homogenate. Sections of liver tissue were also fixed in formol-saline and subjected to histological analysis.

Results: DMN administration caused significant increases in kidney weight, serum ALP, AST, HA, ALT and in liver total collagen content and MDA $(\mathrm{P}<0.05)$ and a significant drop in body and liver weight, liver CAT, GSH and SOD. Histological examination of liver showed that DMN caused congestion, centrilobular, haemorrhagic necrosis, thick collagen fibers deposition and fibrosis. However a combination of $100 \mathrm{mg} / \mathrm{kg}$ each of Vernonia amygdalina and Annona muricata leaves remarkably attenuated and modulated above DMN-induced changes.

Conclusion: This study suggest that combination of Vernonia amygdalina and Annona muricata leaves possess fibrosuppressant, anti-oxidant and anti-hepatotoxic properties against DMN-induced hepatic fibrosis. 


\section{Introduction}

Liver fibrosis is a pre-pathological cirrhotic state, signalized by collagen and extracellular matrix $(\mathrm{ECM})$ proteins accumulation (produced in damaged liver by stellate Cells) in the space of Disse ${ }^{[1-3]}$. DMN, a liver mutagen and carcinogen has been suggested and proven to be a standard model for studying hepatic fibrosis and cirrhosis associated pathophysiological and biochemical changes ${ }^{[4-6]}$.

Vernonia amygdalina (bitter leaf), a leafy vegetable is used for food and disease treatment including liver and kidney problems, diabetes, malaria, infertility, and gastrointestinal problems ${ }^{[7}$; ${ }^{5]}$. Nutritional and phytochemical analysis Vernonia amygdalina leaves have revealed levels of crude protein, crude fiber, carbohydrate, phytochemicals (flavonoids, tannins, saponins etc), mineral components ( $\mathrm{Mg}, \mathrm{Ca}, \mathrm{K}, \mathrm{Na}, \mathrm{Mn}, \mathrm{Zn}, \mathrm{Fe}$ etc) and antioxidant vitamins (A, C, E and riboflavin) ${ }^{[8-11]}$.

Annona muricata, commonly called soursop have its various parts such as bark, roots and leaves for treatment of diseases and ailments including diabetes, liver disease, arthritis, bacterial and fungal problems $[12-14 ; 6]$. Phytochemical screening of Annona muricata leaves has shown it to consist of alkaloids, flavonoids etc as well as mineral elements such as $\mathrm{Na}, \mathrm{Ca}, \mathrm{K}, \mathrm{Fe}, \mathrm{Zn}, \mathrm{Mg}$ etc. Previous studies on Annona muricata showed Annonaceous acetogenins found in the stem, seed and leaves to be cytotoxic against cancer cells ${ }^{[17-18]}$. This study is aimed at the possible fibro-suppressant and antioxidative attenuation of Vernonia amygdalina and Annona muricata leaves in combine dose on liver fibrosis induced by dimethylnitrosamine (DMN) in wistar rats.

\section{Materials and Methods}

\subsection{Plant materials and Extraction}

Annona muricata leaves were collected from the tree in Upper Sakponba while Vernonia amygdalina leaves were purchased from Oba market in Benin City, Nigeria and thereafter a Botanist identified the leaves. Washed and air-dried (at room temperature $\left(24^{\circ} \mathrm{C}\right)$ Annona muricata and Vernonia amygdalina leaves were crushed into fine powder and then weighed. Ethanolic extracts of the powdered leaves were prepared by weighing and soaking $100 \mathrm{~g}$ each of the powdered leaves in $1000 \mathrm{ml}$ of absolute ethanol for $48 \mathrm{hrs}$ (at room temperature). At the end of the 48hours, the extracts were filtered using Whatmann filter paper and cotton wool. The Annona muricata and Vernonia amygdalina ethanolic extracts were thereafter concentrated using a rotary evaporator (set at $60^{\circ} \mathrm{C}$ and $40^{\circ} \mathrm{C}$ respectively) to $1 / 10$ th its original volume followed by freeze drying. The dry powdered crude extract stored at $4^{\circ} \mathrm{C}$ were weighed, dissolved (in distilled water) and used for animal experimental study.

\subsection{Experimental animals}

Wistar rats (48 males, $150-225 \mathrm{~g}$ ) obtained from Animal Unit facility of the University of Ibadan, Ibadan, Nigeria were housed in wooden cages and used for the study. The rats acclimatized for one week, had free access to drinking water and commercial pelleted rat chow (Bendel Feed \& Flour Mill Ltd., Ewu, Nigeria) ad libitum. Ethical clearance/permission were obtained from Institution Animal Ethical Committee before performing the experiments. The DMN was synthesized at the department of Biochemistry, University of Ibadan according to the method of Vogel ${ }^{[19]}$.

The Annona muricata and Vernonia amygdalina leaf extracts weighed and dissolved in distilled water were administered orally using gavage to rats in second and third groups at a dosage of $100 \mathrm{mg} / \mathrm{kg}$ for 14 consecutive days (two weeks). Rats in third group were in addition given DMN (via intraperitoneal injection) at a dose of $10 \mathrm{mg} / \mathrm{kg}$ b.w (dissolved in $0.15 \mathrm{M} \mathrm{NaCl}$ ) in the first three days of each week (for two weeks). Rats in forth group were given same amount of DMN as in third group but without leaf extract, while rats in first group (control group) were given normal saline. By day 15, all the rats were sacrificed (cardiac puncture), blood collected and allowed to stand for $1 \mathrm{hr}$ before centrifuging at for $20 \mathrm{~min}$. The serum samples were stored at $-20^{\circ} \mathrm{C}$ until analyzed. 
Serum was used for determination of hyaluronic acid (HA) level, total bilirubin (TB), total protein (TP), aspartate aminotransaminase (AST), Lactate dehydrohenase (LDH), alanine aminotransaminase (ALT), and alkaline phosphatise (ALP). The livers were immediately excised, washed in cold normal saline and blotted individually. A portion of the weighed liver tissue was fixed in formalin for histopathological examinations while the other portion was stored at $-20^{\circ} \mathrm{C}$ for analysis. $10 \%$ liver tissue homogenate were prepared using normal saline and resulting clear supernatant used for determination of total collagen (ECM component), GSH, CAT, SOD and MDA.

\subsection{Biochemical assays}

Serum LDH, AST, ALT, ALP, TP and TB were determined spectrophotometrically using RANDOX Kit. Serum HA level was determined using ELISA assay kit as described by Chichibu et al ${ }^{[20]}$. Liver total collagen was quantified using QuickZymeR kits. MDA was determined in a colorimetric reaction with thiobarbituric acid ${ }^{[21]}$. SOD was determined according to the method of
Misra and Fridovich [22]. The catalase assay was by measuring the first order rate constant colorimetrically for $\mathrm{H} 2 \mathrm{O} 2$ decomposition ${ }^{[23]}$. GSH was determined according to Ellman ${ }^{[24]}$.

\subsection{Statistical analysis}

Data obtained at the end of this study were expressed as mean \pm SD using Statistical Package for Social Sciences (SPSS). A probability level of less than $5 \%(p<0.05)$ was considered significant.

\section{Results}

The result of liver function enzymes as shown in table 1 showed that dimethylnitrosamine caused massive elevation in ALT, AST, ALP and LDH after two weeks of administration indicating liver toxicity while simultaneous treatment with a combine dose of $100 \mathrm{mg} / \mathrm{kg}$ each of Vernonia amygdalina and Annona muricata significantly reduced the spillage of the enzymes into the blood stream. No significant difference was observed in control rats and rats given VAE and AME alone.

Table 1: Effect of Vernonia amygdalina and Annona muricata on serum liver function enzymes in DMN-induced hepatic fibrotic rats

\begin{tabular}{|l|l|l|l|l|}
\hline Treatment groups & ALT (U/l) & AST (U/l) & ALP (U/l) & LDH (U/1) \\
\hline Control (normal saline) & $11.89 \pm 3.02^{\mathrm{a}}$ & $20.01 \pm 1.99^{\mathrm{a}}$ & $25.22 \pm 2.78^{\mathrm{a}}$ & $200.00 \pm 4.07^{\mathrm{a}}$ \\
\hline $\begin{array}{l}\text { VAE alone }(100 \mathrm{mg} / \mathrm{kg})+ \\
\text { AME alone }(100 \mathrm{mg} / \mathrm{kg})\end{array}$ & $13.99 \pm 4.01^{\mathrm{a}}$ & $21.32 \pm 3.12^{\mathrm{a}}$ & $28.94 \pm 4.25^{\mathrm{a}}$ & $198.89 \pm 5.53^{\mathrm{a}}$ \\
\hline $\begin{array}{l}\text { VAE }(100 \mathrm{mg} / \mathrm{kg})+\mathrm{AME} \\
(100 \mathrm{mg} / \mathrm{kg})+\mathrm{DMN}(10 \mathrm{mg} / \mathrm{kg})\end{array}$ & $47.96 \pm 7.37^{\mathrm{b}}$ & $70.33 \pm 3.03^{\mathrm{b}}$ & $74.53 \pm 3.21^{\mathrm{b}}$ & $325 \pm 10.09^{\mathrm{b}}$ \\
\hline DMN alone $(10 \mathrm{mg} / \mathrm{kg})$ & $89.74 \pm 7.08^{\mathrm{c}}$ & $144.50 \pm 6.87^{\mathrm{d}}$ & $132.01 \pm 7.09^{\mathrm{d}}$ & $543.54 \pm 15.01^{\mathrm{c}}$ \\
\hline
\end{tabular}

Values are means $\pm \mathrm{SD} ; \mathrm{n}=5, \mathrm{VAE}=$ Vernonia amygdalina ethanolic extract, AME $=$ Annona muricata ethanolic extract, $\mathrm{DMN}=$ Dimethylnitrosamine, $\mathrm{ALT}=$ Alanine aminotransaminase, $\mathrm{AST}=$ Aspartate aminotransaminase, $\mathrm{ALP}=\mathrm{Alkaline}$ phosphatase, $\mathrm{LDH}=$ Lactate dehydrogenase Mean values in each column (between groups) having different superscript (a, b, c, d) are significantly different ( $p<$ $0.05)$.

The result of the effect of the Vernonia amygdalina and Annona muricata on oxidative stress parameters (table 2) showed that while DMN caused a significant increase in malondialdehyde (MDA) after two weeks of administration, Vernonia amygdalina and Annona muricata when combined in usage significantly reduced the MDA level indicating protection. Also, table 2 results showed significant decline in CAT, GSH and SOD in DMN administered rats whereas Vernonia amygdalina and Annona muricata when administered simultaneously significantly increased GSH, SOD and catalase. 
Table 2: Effect of Vernonia amygdalina and Annona muricata on oxidative stress parameters in DMN-induced hepatic fibrotic rats

\begin{tabular}{|l|l|l|l|l|}
\hline Treatment groups & $\begin{array}{l}\text { MDA }(\mathrm{U} / \mathrm{mg} \\
\text { wet tissue })\end{array}$ & $\begin{array}{l}\text { Reduced Glutathione } \\
(\mu \mathrm{M} / \mathrm{mg} \text { protein })\end{array}$ & $\begin{array}{l}\text { SOD } \\
(\mathrm{U} / \mathrm{mg} \text { tissue })\end{array}$ & $\begin{array}{l}\text { Catalase } \\
(\mathrm{U} / \mathrm{mg} \text { tissue })\end{array}$ \\
\hline Control $($ normal saline $)$ & $1.87 \pm 0.28^{\mathrm{a}}$ & $50.70 \pm 3.02^{\mathrm{a}}$ & $10.75 \pm 1.18^{\mathrm{a}}$ & $50.43 \pm 4.12^{\mathrm{a}}$ \\
\hline $\begin{array}{l}\text { VAE alone }(100 \mathrm{mg} / \mathrm{kg})+\mathrm{AME} \\
\text { alone }(100 \mathrm{mg} / \mathrm{kg})\end{array}$ & $1.49 \pm 0.65^{\mathrm{a}}$ & $57.89 \pm 5.03^{\mathrm{a}}$ & $13.08 \pm 0.95^{\mathrm{b}}$ & $62.93 \pm 3.04^{\mathrm{a}}$ \\
\hline $\begin{array}{l}\text { VAE }(100 \mathrm{mg} / \mathrm{kg})+\mathrm{AME} \\
(100 \mathrm{mg} / \mathrm{kg})+\mathrm{DMN}(10 \mathrm{mg} / \mathrm{kg})\end{array}$ & $4.16 \pm 0.08^{\mathrm{c}}$ & $31.64 \pm 2.06^{\mathrm{c}}$ & $6.88 \pm 0.87^{\mathrm{c}}$ & $33.06 \pm 2.13^{\mathrm{c}}$ \\
\hline DMN alone $(10 \mathrm{mg} / \mathrm{kg})$ & $8.15 \pm 0.23^{\mathrm{d}}$ & $15.04 \pm 5.00^{\mathrm{d}}$ & $2.12 \pm 0.091^{\mathrm{d}}$ & $13.94 \pm 5.18^{\mathrm{d}}$ \\
\hline
\end{tabular}

Values are means $\pm \mathrm{SD} ; \mathrm{n}=5$, VAE $=$ Vernonia amygdalina ethanolic extract, AME $=$ Annona muricata ethanolic extract, $\mathrm{DMN}=$ Dimethylnitrosamine, $\mathrm{MDA}=$ Malondialdehyde, $\mathrm{SOD}=$ Superoxide dismutase

Mean values in each column (between groups) having different superscript (a, b, c, d) are significantly different ( $\mathrm{p}<$ $0.05)$.

The result of Vernonia amygdalina and Annona muricata on ECM proteins in fibrotic rats induced by DMN as shown in table 3 showed a several folds increase in Hyaluronic acids (HA) and total collagen in rats administered DMN alone whereas in rats simultaneously treated with Vernonia amygdalina and Annona muricata, HA and total collagen where greatly and significantly reduced. Also table 3 showed that Vernonia amygdalina and Annona muricata significantly reduced serum total bilirubin (TB) and significantly increased serum total protein (TP) when compared to rats given DMN alone. There was however no significant difference in control rats and rats given Vernonia amygdalina and Annona muricata alone.

Table 3: Effect of Vernonia amygdalina (VAE) and Annona muricata (AME) on hyaluronic acid (HA), total collagen, total bilirubin (TB) and total protein (TP) in DMN-induced hepatic fibrotic rats

\begin{tabular}{|l|l|l|l|l|}
\hline Treatment groups & HA $(\mathrm{ng} / \mathrm{ml})$ & $\begin{array}{l}\text { Total Collagen } \\
(\mu \mathrm{g} / \mathrm{ml})\end{array}$ & $\mathrm{TB}(\mathrm{mg} / \mathrm{dl})$ & $\mathrm{TP}(\mathrm{g} / \mathrm{l})$ \\
\hline Control (normal saline) & $60.59 \pm 12.78^{\mathrm{a}}$ & $41.01 \pm 2.15^{\mathrm{a}}$ & $0.51 \pm 0.04^{\mathrm{a}}$ & $62.18 \pm 4.06^{\mathrm{a}}$ \\
\hline $\begin{array}{l}\text { VAE alone }(100 \mathrm{mg} / \mathrm{kg})+\text { AME alone } \\
(100 \mathrm{mg} / \mathrm{kg})\end{array}$ & $61.22 \pm 3.16^{\mathrm{a}}$ & $42.17 \pm 3.13^{\mathrm{a}}$ & $0.61 \pm 0.02^{\mathrm{a}}$ & $65.23 \pm 2.13^{\mathrm{a}}$ \\
\hline $\begin{array}{l}\text { VAE }(100 \mathrm{mg} / \mathrm{kg})+\text { AME }(100 \mathrm{mg} / \mathrm{kg}) \\
+ \text { DMN }(10 \mathrm{mg} / \mathrm{kg})\end{array}$ & $195.80 \pm 10.14^{\mathrm{b}}$ & $59.76 \pm 7.58^{\mathrm{b}}$ & $1.10 \pm 0.05^{\mathrm{c}}$ & $53.01 \pm 5.42^{\mathrm{b}}$ \\
\hline DMN alone $(10 \mathrm{mg} / \mathrm{kg})$ & $460.11 \pm 10.21^{\mathrm{c}}$ & $126.01 \pm 6.94^{\mathrm{c}}$ & $2.91 \pm 0.21^{\mathrm{d}}$ & $32.92 \pm 2.22^{\mathrm{d}}$ \\
\hline
\end{tabular}

Values are means $\pm \mathrm{SD} ; \mathrm{n}=5$, VAE $=$ Vernonia amygdalina ethanolic extract, AME $=$ Annona muricata ethanolic extract, $\mathrm{DMN}=$ Dimethylnitrosamine, $\mathrm{HA}=$ Hyaluronic acid, $\mathrm{TB}=$ Total Bilirubin, $\mathrm{TP}=$ Total protein

Mean values in each column (between groups) having different superscript ( $a, b, c, d)$ are significantly different $(\mathrm{p}<$ $0.05)$.

\section{Discussion}

Connective tissue proteins accumulation such as Collagen and Hyaluronic acid (HA) has been reported and its measurement can serve in quantifying fibrosis ${ }^{[25]}$. In this study by day 15 , total collagen was increased linearly following administration of DMN (Table 3), an indication of hepatic fibrosis similar to previous reports ${ }^{[4 ; 26-28]}$. The hyaluronic acid increase in this study could be explained by its increased synthesis by activated hepatic stellate cells (HSCs) resulting in its simultaneous leakage into the blood stream along with the liver function enzymes. The high rise in hyaluronic acid may also be as a result of its degradation by hyaluronidases enzymes [29]. However, the combination of Vernonia amygdalina and Annona muricata leaves showed anti-fibrogenic activity expressed in decrease of total collagen and hyaluronic acid content most probably due to the antioxidants and phytochemicals present in the leaves. Liver CYP2E1 is the main CYP involved in DMN activation. It is possible that the decrease in hepatic CYP2E1 activity by Vernonia amygdalina 
and Annona muricata leaves affected the activation of DMN resulting in a reduction of Hepatic stellate cells activation and consequent decrease in total collagen and HA. The decrease of HA activity by Vernonia amygdalina and Annona muricata leaves may also be due to HA degrading enzymes activation. The protective effect of Vernonia amygdalina and Annona muricata leaves is in tandem with similar studies by Shin and Moon [30]; Yan et al ${ }^{[31]}$; George et al ${ }^{[32]}$.

In this study, DMN administration caused a marked rise in serum AST, LDH, ALT, ALP and bilirubin, indicating damage of the liver and consequent cytolysis of hepatic cells similar to previous reports $[4 ; 26 ; 33-35]$. The release of the liver function enzymes from cytoplasm into blood can be said to be due to rupture of plasma membrane and cell damage. The high rise in AST compare to ALT may be due to mitochondrial AST release into the blood stream, a consequence of severe hepatocyte damage. The rise in serum bilirubin could be due to hemolysis. The results of George ${ }^{[36-37]}$ were similar to our findings which reported significant increase in liver function enzymes in mice/rats treated with DMN intraperitoneally. Consequently, a combined dose of Vernonia amygdalina and Annona muricata leaves against DMN-induced fibrosis significantly reduced the levels of liver function enzymes compared to rats given only $\mathrm{DMN}$, an indication that the leaves offered protection against liver cell damage. The reverse in liver marker enzyme activities may also be attributed to the ability of Vernonia amygdalina and Annona muricata leaves to inhibit hepatic P4502E1 activity. The protection offered by Vernonia amygdalina and Annona muricata in this study is similar to previous studies of George et al ${ }^{[32]}$ and Shin and Moon ${ }^{[30]}$. In a related study by Sharma and Singh ${ }^{[38]}$, Operculina turpethum ethanolic root extract showed therapeutic effects by restoring AST, ALT and ALP levels.

Lipid peroxidation (with Malondialdehyde, MDA considered its most significant indicator) is the most recognized mechanism in studying liver injury pathogenesis by several toxic agents ${ }^{[39-41]}$. In this study, the massive rise in MDA is an indication that DMN-induced damage of liver cell membrane results in free radical production thereby enhancing oxidative stress. In this study, however, simultaneous supplementation with combined dose of Vernonia amygdalina and Annona muricata leaves significantly reduced MDA levels, an indication that the plant leaves can scavenge and detoxify free radicals similar to previous findings of Shin and Moon ${ }^{[30]}$ and George et al ${ }^{[32]}$.

Also in this study, antioxidant component of self-defense system (GSH, CAT, and SOD) were reduced in rats given DMN, a finding similar to previous investigations ${ }^{[42-45]}$. The continuous mitochondria production of superoxide radical might be responsible for the reduction in liver SOD and CAT in rats given DMN. The drop in CAT, SOD and GSH biosynthesis during liver cell damage might be responsible for the depletion in the non-enzymatic and enzymatic self-defense component. However, treatment with combined dose of Vernonia amygdalina and Annona muricata leaves simultaneously with DMN significantly raised the antioxidants (SOD, CAT and GST) compared to rats given only DMN. Vernonia amygdalina and Annona muricata leaves contain phytochemical compounds such as flavonoids with strong free radical scavenging potentials. These protection offered by combined dose of both leaves is similar to previous work of Sharma and Singh ${ }^{[38]}$.

\section{Conclusion}

In conclusion, Vernonia amygdalina and Annona muricata leaves possess synergistic, antifibrotic, free radical scavenging and hepatoprotective potentials against DMN-induced liver disease and the bioactive agents including flavonoids in both leaves may be responsible.

\section{Conflict of Interest}

We the authors hereby declare no conflict of interest.

\section{References}

1 Shimizu I, Ma YR, Mizobuchi Y, Liu F, Miura T, Nakai Y. Effects of Sho-saikoto, a Japanese herbal medicine, on hepatic fibrosis in rats. Hepatol 1999; 29:149 - 160. DOI: 10.1002/hep.510290108

2 Poli G. Pathogenesis of liver fibrosis: role of oxidative stress. Mol Aspects Med 2000; 21:49-98. 
3 Rojkind M, Giambrone MA, Biempica L. Collagen types in normal and cirrhotic liver. Gastroentero 1979; 76:710-719. DOI: 10.1016/S0016-5085(79)80170-5

4 George J, Rao KR, Stern R, Chandrakasan G. Dimethyl-nitrosamine-induced liver injury in rats: the early deposition of collagen. Toxicol 2001; 156(2-3):129-138.

5 Usunomena U, Okolie NP, Eze IG. Inhibitory Effect of Vernonia amygdalina on Dimethylnitrosamine (DMN)-induced Liver Fibrosis in Rats. Int J Clin Pharmacol Toxicol 2015a;4(4):179-184.

6 Usunobun U,Okolie NP, Eze IG.Attenuation of $\mathrm{N}$, N-Dimethylnitrosamine-induced liver Fibrosis in rats by ethanolic leaf extract of Annona muricata. Saudi J Med Pharmaceut Sci 2015b; 1(2):62- 69.

7 Farombi EO, Owoeye O. Antioxidant and chemopreventive properties of Vernonia amygdalina and Garcinia biflavonoid. Int $J$ Env Res Pub Health 2011; 8:2533 - 2555. DOI: 10.3390/ijerph8062533

8 Atangwho IJ, Ebong PE, Eyong EU, Williams IO, Eteng MU, Egbung GE. Comparative chemical composition of leaves of some antidiabetic medicinal plants: Azadirachta indica, Vernonia amygdalina and Gongronema latifolium. Afr J Biotechnology 2009; $8(18): 4685$ - 4689.

9 Igile GO, Oleszek W, Jurzysta M, Burda S, Fanfunso M, Fasanmade AA. Flavonoids from Vernonia amygdalina and their antioxidant activities. J Agric Food Chem 1994; 42:2445 - 2448. DOI: $10.1021 / \mathrm{jf00047a015}$

10 Usunobun U, Okolie NP. Phytochemical, trace and mineral composition of Vernonia amygdalina leaves. Int J Biol Pharmaceuti Res 2015a; 6(5):393-399.

11 Usunobun U,Okolie PN.Phytochemical analysis and proximate composition of Vernonia amygdalina. Int J Sci World 2016; 4(1):11-14. DOI: $\underline{10.14419 / \mathrm{ijsw} . v 4 i 1.5845}$

12 Adeyemi D, Komolafe O, Adewole S, Obuotor EM, Adenowo T. Antihyperglycemic activities of Annona muricata. Afr J Tradit Complement Altern Med 2008; 6:62 - 69

13 Adeyemi DO,Komolafe OA,Adewole OS, Obuotor EM, Abiodun AA, Adenowo TK.
Histomorphological and morpholometric studies of the pancreatic islet cell of diabetic rats treated with extracts of Annona muricata. Folia Morphol 2010; 69:92 - 100.

14 Takahashi JA, Pereira CR, Pimenta LP, Boaventura MA, Silva LG. Antibacterial activity of eight Brazilian Annonaceae plants. Nat Prod Res 2006; 20(1):21-26.

15 Usunobun U, Okolie NP, Anyanwu OG, Adegbegi AJ, Egharevba ME. Phytochemical screening and proximate composition of Annona muricata leaves. Eur J Bot Plant Sci Phytolo 2015c; 2(1):18-28.

16 Usunobun U,Okolie NP.Phytochemical analysis and mineral composition of Annona muricata leaves. Int J Res Curr Develop 2015b; 1(1):38-42.

17 Chang FR, Wu YC. Novel cytotoxic annonaceous acetogenins from Annona muricata. J Nat Productivity 2001; 64: 925 931. DOI: $10.1021 / \mathrm{np} 010035 \mathrm{~s}$

18 Liaw CC, Chang FR, Lin CY, Chou CJ, Chiu $\mathrm{HF}$, Wu MJ, et al. New cytotoxic monotetrahydrofuran annonaceous acetogenins from Annona muricata. J Nat Productivity 2002;65:470 - 475. DOI: 10.1021/np0105578

19 Vogel AI. A textbook of practical organic Chemistry including qualitative organic analysis.Longman group limited, London. 1971; 426.

20 Chichibu K, Matsuura, T, Shichijo S. Assay of serum hyaluronic acid in clinical application. Clinica Chimica Acta 1989; 181:317-324.

21 Ohkawa H, Ohishi N, Yogi K. Assay for lipid peroxidation in animal tissues by thiobarbituric acid reaction. Annals Biochem 1979; 95:351 - 358.

22 Misra HP, Fridovich I. The role of superoxide ion in the autooxidation of epinephrine and a simple assay of superoxide dismutase. $\boldsymbol{J}$ Biol Chem 1972; 247:3170 - 3175.

23 Cohen G, Dembiec D, Marcus J. Measurement of catalase activity in tissues. Analyt Biochem 1970; 34:30-38.

24 Ellman GL. Tissue sulfhydryl groups. Arch Biochem Biophys 1959; 82:70 - 77.

25 Yuan GJ, Zhang,ML, Gong ZJ. Effect of PPAR agonist pioglitazone on rat hepatic fibrosis. 
World J Gastroenterol 2004; 10:1047 - 1051. DOI: $10.3748 /$ wjg.v10.i7.1047

26 George, J , Chandrakasan G. Biochemical abnormalities during the progression of hepatic fibrosis induced by dimethylnitrosamine. Clin Biochem 2000; 33(7): 563-570.

27 Iimuro Y, Fujimoto J. Strategy of gene therapy for liver cirrhosis and hepatocellular carcinoma. J Hepatobiliary Pancreat Surg 2003; 10(1):45-47. DOI: $10.1007 / \mathrm{s} 10534-002-0790-\mathrm{Z}$

$28 \mathrm{Mu}$ YP, Liu P, Liu Y, Li FH, Chen GF, Gu HT, et al. Inhibiting action of Xiayuxue decoction on hepatic fibrosis at progressive stage in rats and study on the prescription and syndrome. $\boldsymbol{J}$ Tradit Chin Med 2006; 47:215-218

29 Fraser JRE, Laurent TC, Laurent UBG. Hyaluronan: its nature, distribution, functions and turnover. J Internal Med 1997; 242(1):2733. DOI: $10.1046 / \mathrm{j} .1365-2796.1997 .00170 . \mathrm{x}$

30 Shin M , Moon J. Effect of dietary supplementation of grape skin and seeds on liver fibrosis induced by dimethylnitrosamine in rats. Nutri Res Pract 2010; 4(5):369-374. DOI: $10.4162 / \mathrm{nrp} .2010 .4 .5 .369$

31 Yan W, Juncha G, Di Z, Jian Z, Junji M, Huiqing J. New insights into the antifibrotic effects of sorafenib on hepatic stellate cells and liver fibrosis. J Hepatol 2010; 53:132 - 144

32 George J , Suguna L, Jayalakshmi R, Chandrakasan G. Efficacy of Silymarin and Curcumin on dimethyl nitrosamine induced liver fibrosis in rats, Biomedicine 2006; 26(3 - 4): $18-26$.

33 Bansal AK, Bansal M, Soni G, Bhatnagar D. Protective role of Vitamin E pre-treatment on $\mathrm{N}$-nitrosodiethylamine induced oxidative stress in rat liver. Chem Biol Interact 2005; 156(23):101-111. DOI: 10.1016/j.cbi.2005.08.001

34 Vimal V, Devaki T. Hepatoprotective effect of allicin on tissue defense system in galactosamine/endotoxin challenged rats. $\boldsymbol{J}$ Ethnopharmacol 2004; 90:151 - 154

35 Yanpallewar SU, Sen S, Tapas S, Kumar M, Raju SS, Acharya SB. Effect of Azadirachta indica on paracetamol-induced hepatic damage in albino rats. Phytomed 2003; 10:391-396.

36 George J . Mineral metabolism in dimethylnitrosamine-induced hepatic fibrosis.
Clin Biochem 2006; 39:984 - 991. DOI: 10.1016/j.clinbiochem.2006.07.002

37 Qing-Wei H, Geng-Tao L. Effects of bicyclol on dimethylnitrosamine-induced liver fibrosis in mice and its mechanism of action. Life Sci 2006; 79:606 - 612. DOI: 10.1016/j.lfs.2006.02.025

38 Sharma V, Singh M. Attenuation of Nnitrosodimethylamine induced hepatotoxicity by Operculina turpethum in Swiss Albino mice. Iran J Basic Med Sci 2014; 17:73-80.

39 Vendemiale G,Grattagliano I, Caruso ML, Serviddio G, Valentini AM, Pirrelli M, Altomare E.Increased oxidative stress in dimethylnitrosamine-induced liver fibrosis in the rat: effect of $\mathrm{N}$-acetylcysteine and interferon-alpha. Toxicol Appl Pharmacol 2001; 175:130-9. DOI:10.1006/taap.2001.9234

40 George J. Ascorbic acid concentrations in dimethylnitrosamine-induced hepatic fibrosis in rats, Clin Chim Acta 2003; 335:39 - 47. DOI: 10.1016/S0009-8981(03)00285-7

41 Halliwell B,Gutteridge JMC. The definition and measurement of antioxidants in biological systems. Free Radic Biol Med 1995; 18:125126. DOI: $\underline{10.1016 / 0891-5849(95) 91457-3}$

42 Priya S,Vijayalakshmi P, Vivekanandan P, Karthikeyan S. N-Acetylcysteine attenuates dimethylnitrosoamine induced oxidative stress in rats. Eur J Pharmacol 2011a; 654:181-186. DOI: $10.1016 /$ j.ejphar.2010.10.080

43 Priya S, Vijayalakshmi, P, Vivekanandan, P, Karthikeyan S. Influence of $\mathrm{N}$-acetylcysteine against dimethylnitrosoamine induced hepatotoxicity in rats. Toxicol Ind Health 2011b;27(10):914 - 922. DOI: $\underline{10.1177 / 0748233711399323}$

44 Hong SW, Jung KH, Zheng HM, Lee HS, Suh JK, Park IS, Lee DH, Hong SS, The protective effect of resveratrol on dimethylnitrosamineinduced liver fibrosis in rats. Arch Pharm Res 2010; 33(4):601 - 609. DOI: $\underline{10.1007 / \mathrm{s} 12272-}$ 010-0415-y

45 Wang JH, Shin JW, Son JY, Cho JH, Son CG. Antifibrotic effects of CGX, a traditional herbal formula, and its mechanisms in rats. $\boldsymbol{J}$ Ethnopharmacol 2010; 127:534 - 542. DOI: 10.1016/j.jep.2009.10.001 